\section{Viruses Detected in Stone Fruit Germplasm Entering the United States}

\author{
Howard E. Waterworth \\ U.S. Department of Agriculture, Agricultural Research Service, 11601 Old \\ Pond Drive, Glenn Dale, MD 20769
}

Additional index words. Prunus, plant quarantine, plum pox, virus indexing

Except stone fruit from Canada and cherry seed from all countries, stone fruit germplasm (Prunus spp.) must be sent to the National Plant Quarantine Center on arrival in the United States. Thus, germplasm can be imported only by the U.S. Dept. of Agriculture and must be held in quarantine for 3 to 4 years while it is tested for pathogens (U.S. Dept. of Agriculture, 1992). Prunus spp. is prohibited because it may be infected with submicroscopic pathogens [i.e., viruses, viroids, mycoplasma-like organisms (MLO), or unknown infectious agents].

Compared with other perennial crops, stone fruit seem to be unusually prone to many virus-like disorders. Nemeth (1986) listed and described 161 diseases of the five stone fruit crops that are associated with submicroscopic pathogens. Of these diseases, $40 \%$ have been reported only in North America, but another $43 \%$ are not known to occur in the United States. Some of these pathogens, such as plum pox (sharka) and tomato ringspot viruses, have been destructive in Europe and the United States, respectively. Other diseases are obscure, do not appear to have economic importance, or may be caused by strains of wellknown pathogens.

My objective was to report results of tests completed during the last 3 years for virus and virus-like pathogens in introduced Prunus germplasm. When the Prunus arrived in quarantine, vegetative accessions were budded onto virus-free rootstocks; and accessions of seed were sown after stratification. Resulting plants were closely monitored for symptoms of disease and subjected to a battery of tests for virus and virus-like pathogens. Tests were conducted to detect all known pathogens, whether or not they were already widespread within the United States. The Animal and Plant Health Inspec-

Received for publication 7 Oct. 1993. Accepted for publication 14 Feb. 1994. I thank Ray Mock and Jan Bowman for expert technical assistance and Billy Newell for the GF305 peach seed. The cost of publishing this paper was defrayed in part by the payment of page charges. Under postal regulations, this paper therefore must be hereby marked advertisement solely to indicate this fact. tion Service (APHIS) specified what tests would be conducted. Introductions that were pathogen free were released from quarantine by APHIS for distribution to U.S. breeders and repositories (Foster, 1988). Introductions infected with pathogens that were widely distributed in the United States could be distributed on approval from the state department of agriculture for the importing state.

Three kinds of tests were used to detect these pathogens. One involved rubbing sap extracted from leaves of the foreign accessions onto selected herbaceous species known to be sensitive to some of the viruses that infect Prunus. In a second test, enzyme-linked immunosorbant assay serological tests (ELISA) were used to detect several of the well-characterized viruses. These two rapid tests can be completed in $<3$ weeks. The 30 known virus and viroid pathogens can be detected, and $85 \%$ of them can be identified by these methods.

A third test was required to detect the many uncharacterized infectious agents (Waterworth, 1993). Because nothing is known about these causal agents, there are no herbaceous indicators or serological tests available. These agents can be detected only by grafting or budding tissue from introductions onto another Prunus variety known to exhibit symptoms if specific infectious agents are present. Some incite disease in indicator leaves within a few months, but others produce symptoms only in fruit, usually after several years. Some of these tests were conducted in the field.

Eleven woody indicators were used in graft tests to detect uncharacterized infectious agents

Table 1. Pathogens detected in foreign Prunus accessions while in quarantine (1991-93). ${ }^{ }$

\begin{tabular}{lcc}
\hline \hline & \multicolumn{2}{c}{ No. accessions } \\
\cline { 2 - 3 } Pathogen & Tested & Infected \\
\hline Necrotic ringspot virus & 452 & 14 \\
Prune dwarf virus & 430 & 16 \\
Green ring mottle virus & 408 & 5 \\
Plum pox (sharka) virus & 480 & 7 \\
Virus-like pathogens & 610 & 12 \\
\hline
\end{tabular}

${ }^{2}$ In addition, virus-like symptoms were observed in trees of 30 accessions, especially in peach and almond. and the five MLO pathogens that infect Prunus. Each indicator detects from one to 15 different pathogens. They represented all five stone fruit types: 'Peerless' almond [Prunus dulcis (Mill.) D. Webb]; 'Tilton' and 'Luizet' apricot $(P$. armeniaca L.); 'Shirofugen' and 'Kwanzan' ( $P$. serrulata Lindl.) and 'Bing' and 'Sam' (P. avium L.) cherry; 'GF305' and 'Elberta' peach [P. persica (L.) Batsch]; and 'Shiro' and 'Pozagaca' (P. domestica L.) plum. Final readings were taken after the field-grown indicators ('Peerless', 'Tilton', 'Luizet', 'Bing', 'Sam', 'Elberta', and 'Pozagaca') fruited, usually 3 years after inoculation.

Viruses were detected in 5\% of the accessions (26 of 521) tested from 1991 to 1993. Prunus necrotic ringspot virus (NRSV) and prune dwarf virus (PDV) were detected most often (Table 1). Plum pox virus (PPV) was detected for the first time in several accessions of peach, plum, and apricot from Romania and Yugoslavia. Virus-like symptoms also were expressed in tests of 12 additional accessions, but pathogens have not been identified. Some of the viruses were detected by more than one type of test (e.g., NRSV and PDV by the herbaceous test, 'Shirofugen' indicator, and ELISA serology). Virus-like symptoms also were observed in trees of 30 additional accessions from other countries.

Some susceptible accessions have been replaced by reintroductions of the same varieties from overseas. Others have been subjected to thermal therapy as a means to obtain pathogen-free tissue.

There is no absolute way to quantify the value of intercepting these pathogens in imported Prunus germplasm. Although NRSV and PDV are widespread in the United States, these viruses occur as many biologically different strains-some are severe and some do not occur in the United States. Plum pox virus, not known in the United States, is considered to be the most destructive of the Prunus submicroscopic pathogens. It occurs throughout Europe and parts of Asia where $80 \%$ of Prunus accessions originate.

\section{Literature Cited}

Foster, J.A. 1988. Regulatory actions to exclude pests during the international exchange of plant germplasm. HortScience 23:60-66.

Nemeth, M. 1986. Virus, mycoplasma and rickettsia diseases of fruit trees. Kluwer Academic Publ., Dordrecht, The Netherlands.

U.S. Dept. of Agriculture. 1992. Nursery stock, plants, roots, bulbs, seeds, and other plant products. Animal and Plant Health Inspection Ser. Plant Protection \& Quarantine Regulations. U.S. Dept. of Agr. 7 CFR 319.37. U.S. Govt. Printing Office, Washington, D.C.

Waterworth, H.E. 1993. Processing foreign plant germplasm at the National Plant Germplasm Quarantine Center. Plant Dis. 77:854-860. 